\title{
Pulmonary Dysfunction after Treatment for Childhood Cancer: Comparing Multiple-Breath Washout with Spirometry
}

Christina Schindera, $\mathrm{MD}^{1,2,3^{*}}$, Jakob Usemann, MD, PhD ${ }^{4,5,6 *}$, Simeon Joel Zuercher, $\mathrm{PhD}^{7}$, Ruedi Jung, $\mathrm{MSc}^{7}$, Rahel Kasteler, MD, $\mathrm{PhD}^{3}$, Bettina Frauchiger, $\mathrm{MD}^{5}$, Geraldine Naumann ${ }^{1}$, Corina

Silvia Rueegg, $\mathrm{PhD}^{8}$, Philipp Latzin, $\mathrm{MD}, \mathrm{PhD}^{5}$, Claudia Elisabeth Kuehni, $\mathrm{MD}^{2,5^{\dagger}}$, Nicolas Xavier von der Weid, $\mathrm{MD}^{1+}$

* shared first co-authorship, ${ }^{\dagger}$ shared last co-authorship

\section{ORCID IDs for each author:}

Christina Schindera: 0000-0002-4511-287X

Jakob Usemann: 0000-0002-9987-2866

Rahel Kasteler: 0000-0002-0856-3436

Bettina Frauchiger: 0000-0002-9519-9328

Corina Silvia Rueegg: 0000-0003-3720-4659

Philipp Latzin: 0000-0002-5239-1571

Claudia Kuehni: 0000-0001-8957-2002

Nicolas von der Weid: 0000-0002-9555-3817

1 - Pediatric Oncology/Hematology, University Children`s Hospital Basel, Switzerland

2 - Institute of Social and Preventive Medicine, University of Bern, Switzerland

3 - Pediatric Hematology/Oncology, University Children's Hospital Bern, Switzerland

4 - Pediatric Respiratory Medicine, University Children's Hospital Basel, Switzerland

5 - Pediatric Respiratory Medicine, University Children's Hospital Bern, Switzerland

6 - Division of Respiratory Medicine, University Children's Hospital Zurich, Switzerland;

7 - Epidemiology, Biostatistics and Prevention Institute, University of Zurich, Switzerland

8 - Oslo Centre for Biostatistics and Epidemiology, Oslo University Hospital, Norway

\section{Corresponding Author:}

Prof. Claudia E. Kuehni, MD; Swiss Childhood Cancer Registry, Institute of Social and Preventive Medicine, University of Bern, Mittelstrasse 43, 3012 Bern, Switzerland; E-mail:

claudia.kuehni@ispm.unibe.ch; Telephone: +41316313507

Author Contributions: Conception and design of the study: PL, NVDW, CSR; acquisition of data: CS, JU, RK, BF, SZ, RJ, GN; statistical analysis: CS, JU, CEK; interpretation: PL, CEK, JU, CS, NVDW; drafting the work: CS, JU, CEK. All authors edited, reviewed, and approved the final version of the manuscript. All authors agree to be accountable for all aspects of the work in ensuring that questions related to the accuracy or integrity of any part of the work are investigated and resolved.

Disclosure Statement: Dr Christopher Ritter contributed to the writing of the manuscript by editorial assistance.

Grants: Swiss Cancer League (KLS-3175-02-2013, KLS-3886-02-2016), Swiss Cancer Research (KFS-4157-02-2017), Stiftung für krebskranke Kinder, Regio Basiliensis, FORCE - Fondation 
Recherche sur le Cancer de l'Enfant, Gedächtnis-Stiftung Susy Rückert zur Krebsbekämpfung, Fond'Action, Taecker Stiftung, Stiftung Krebshilfe Zürich Schweiz, Stiftung Henriette \& HansRudolf Dubach-Bucher.

Abstract previously published at the SSC/SSCS SSP/SSTS Joint Annual Meeting 2020.

Running Head: Pulmonary dysfunction after childhood cancer (45/50 characters)

ATS Subject Category: 14.04

MeSH Key Words: Survivors of Childhood Cancer, Follow-Up Care, Pulmonary Disease

Word Count: 3205

This article has an online supplement, which is accessible from this issue's table of content online at www.atsjournals.org 


\section{Abstract}

Rationale: Childhood cancer survivors are at risk of long-term pulmonary dysfunction, but we lack sensitive outcome measures to detect early pulmonary damage.

Objective: To assess the ability of nitrogen multiple-breath washout $\left(\mathrm{N}_{2} \mathrm{MBW}\right)$ for detecting pulmonary dysfunction compared to spirometry in long-term survivors of childhood cancer.

Methods: We analyzed cross-sectional data from long-term ( $\geq 5$-year) survivors of childhood cancer, aged $\leq 16$ years at cancer diagnosis, $\geq 16$ years at study (assessment period $2015-2019$ ). We categorized survivors by risk: high risk for those having had pulmotoxic chemotherapy, chest radiation, thoracic surgery, and/or hematopoietic stem cell transplantation, and standard risk for other cancer therapies. Primary outcomes were the global lung clearance index (LCI) and acinar ventilation inhomogeneity index $\left(\mathrm{S}_{\mathrm{ACIN}}\right)$ from $\mathrm{N}_{2} \mathrm{MBW}$, and forced expiratory volume in one second $\left(\mathrm{FEV}_{1}\right)$ and functional vital capacity (FVC) from spirometry. We calculated z scores for $\mathrm{N}_{2} \mathrm{MBW}$ and spirometry parameters and compared pulmonary dysfunction between risk groups. Pulmonary dysfunction was defined as $z$ score +1.64 for $\mathrm{N}_{2} \mathrm{MBW}$ and -1.64 for spirometry.

Results: We studied 46 survivors, median age at diagnosis 10 years (interquartile range [IQR] 414), median age at study 30 years (IQR 25-40). Thirty-seven percent were at high risk and 63\% at standard risk for pulmonary dysfunction. $\mathrm{LCl}$ and $\mathrm{S}_{\mathrm{ACIN}}$ were higher in the high risk group compared to the standard risk group (mean LCl z scores 2.09, standard deviation [SD] 2.39 vs 0.95, SD 2.81; mean $\mathrm{S}_{\mathrm{ACIN}} Z$ scores 2.45 , SD 3.29 vs 0.65, SD 2.79). $F E V_{1}$ and $F V C$ were lower in the high risk compared to the standard risk group (mean $\mathrm{FEV}_{1} z$ scores -0.94 , SD 1.39 vs -0.10 , SD 1.07; mean FVC $z$ scores -1.14, SD 1.23 vs 0.15, SD 1.61). Overall, $L C l, S_{A C I N}, F E V_{1}$, and FVC 
were abnormal in $60 \%, 53 \%, 33 \%$, and $33 \%$ of high risk patients compared to $23 \%, 21 \%, 0 \%$, and $4 \%$ of standard risk patients.

Conclusions: $\mathrm{N}_{2} \mathrm{MBW}$ identified more cases of pulmonary dysfunction in long-term survivors of childhood cancer than spirometry, even in patients who had cancer therapy not specifically known as being pulmotoxic. $\mathrm{N}_{2} \mathrm{MBW}$ could be a complementary screening tool for early pulmonary damage after treatment for childhood cancer.

Clinical trial registered with ClinicalTrials.gov (NCT02730767).

Abstract Word Count: 350 
Pulmotoxic cancer treatment can cause long-term pulmonary damage $(1,2)$ leading to a 15 -fold increased mortality compared to the general population (3). There is clear evidence for pulmotoxicity for some treatments such as bleomycin and chest radiation for which guidelines recommend surveillance (4). A number of other chemotherapies are suspected of damaging the lungs (5-9), but solid data are lacking. Because symptomatic disease occurs relatively late due to the large functional reserve of the lungs and a long silent period (10), early screening for functional changes is necessary.

Spirometry currently is recommended for screening childhood cancer survivors (4) even though it mainly measures changes in the large airways and is insensitive to small airway damage potentially caused by cancer treatment. Increasingly, though, nitrogen multiple-breath washout ( $\mathrm{N}_{2} \mathrm{MBW}$ ) is being used to measure ventilation inhomogeneity and small airway disease (11). Its main outcome indices are the lung clearance index (LCI), a marker for global ventilation inhomogeneity, and the acinar ventilation inhomogeneity index $\left(\mathrm{S}_{\mathrm{ACIN}}\right)$, which measures global and acinar ventilation inhomogeneity. $\mathrm{N}_{2} \mathrm{MBW}$ is more sensitive than spirometry for the detection of early pulmonary disease in children with cystic fibrosis $(12,13)$, in pediatric patients undergoing hematopoietic stem cell transplantation (HSCT) (14) and lung transplantation $(15)$, and in adults after $\operatorname{HSCT}(14,16)$. It has not yet been used with childhood cancer survivors.

Pulmotoxic chemotherapy (17), chest radiation (18), and HSCT can damage the alveolar, vascular, and parenchymal lung compartments. The histopathological process involves inflammation where cytokines and growth factors stimulate collagen production by fibroblasts, leading to lung fibrosis (Figure 1) (18). Initially, this damage occurs in the small airway 
compartments, resulting in reduced ventilation of the lung periphery and impaired diffusion. The $\mathrm{N}_{2} \mathrm{MBW}$ could be a sensitive test to assess ventilation inhomogeneity resulting from early fibrotic damage. As the fibrosis progresses, also larger airways may be damaged, resulting in airway obstruction and restriction, which can be measured with spirometry. Previous studies in childhood cancer survivors have shown signs of reduced lung volumes and reduced oxygen diffusion capacity, which are both indicative for fibrosis, but only very few survivors had signs of airway obstruction (19). To the best of our knowledge, no previous study in childhood cancer survivors has used the $\mathrm{N}_{2} \mathrm{MBW}$ test to assess early pulmonary damage. Since lung fibrosis starts in the smaller airways, we hypothesized that $\mathrm{N}_{2} \mathrm{MBW}$ would detect more cases of pulmonary dysfunction than spirometry. We further hypothesized that high risk survivors would show more pulmonary dysfunction than standard risk survivors of childhood cancer. This study measured pulmonary function in adult survivors of childhood cancer, and it compared $\mathrm{N}_{2} \mathrm{MBW}$ and spirometry results in high risk survivors exposed to confirmed pulmotoxic treatment and standard risk survivors treated with other cancer therapies.

\section{Methods}

\section{Study Design and Study Population}

We enrolled childhood cancer survivors participating in the SURfit study (20). SURfit is a randomized controlled, physical activity intervention study conducted between 2015 and 2019 at the University Children's Hospital Basel, Switzerland. Participants were recruited through the Swiss Childhood Cancer Registry, a nationwide registry of all patients diagnosed with leukemia, 
lymphoma, central nervous system tumors, malignant solid tumors, or Langerhans cell histiocytosis before age 21 years in Switzerland (21). Inclusion criteria for SURfit were age $\leq 16$ years at cancer diagnosis, survival of five years or more since cancer diagnosis, and age at study $\geq 16$ years. Participants were randomized 1:1 to an intervention group with 2.5 hours of physical activity per week additional to individual baseline activity, and a control group with continuation of individual baseline activity.

We conveniently sampled participants from two risk groups for pulmonary dysfunction: 1) high risk for pulmonary dysfunction due to exposure to established pulmotoxic cancer treatments including busulfan, bleomycin, carmustine, lomustine, chest radiation, thoracic surgery, and/or HSCT (4), and 2) standard risk for pulmonary dysfunction due to other chemotherapies $(5-9,22)$. Within these groups, we recruited SURfit participants who agreed to undergo additional pulmonary function assessment. Pulmonary function was measured crosssectionally three months after randomization in the SURfit study for organizational reasons. We did not expect any change of pulmonary function in survivors who increased their physical activity levels due to the intervention. Nevertheless, we adjusted for study group in a sensitivity analysis.

Ethics approval was granted by the Swiss Ethics Committee on research involving humans (Ethikkommission Nordwest- und Zentralschweiz [EKNZ], reference number: EKNZ2015-169), and the SURfit study was registered at ClinicalTrials.gov (identifier: NCT02730767). 


\section{Nitrogen Multiple-Breath Washout}

Pulmonary function was measured by one experienced technician in a specialized pulmonary function laboratory at the University Children's Hospital Basel, Switzerland. The technician was blinded to the risk group of survivors. All $\mathrm{N}_{2} \mathrm{MBW}$ measurements were performed according to the European Respiratory Society and American Thoracic Society consensus statement (23) on the same commercially available device (Exhalyzer D, Spiroware 3.1.6, Eco Medics AG). Main $\mathrm{N}_{2} \mathrm{MBW}$ indices were $\mathrm{LCl}$, conductive ventilation inhomogeneity index $\left(\mathrm{S}_{\mathrm{COND}}\right), \mathrm{S}_{\mathrm{ACIN}}$, and functional residual capacity (FRC). We calculated $z$ scores using published reference values from healthy adults (24).

\section{Spirometry}

Spirometry was performed after $\mathrm{N}_{2} \mathrm{MBW}$ using the same Jaeger MasterScreen (CareFusion, Hochberg, Germany) device according to the European Respiratory Society and American Thoracic Society consensus statement (25). Main spirometry indices were forced expiratory volume in one second $\left(\mathrm{FEV}_{1}\right)$, forced vital capacity $(\mathrm{FVC})$, and the Tiffenau index (FEV $\left.1 / F V C\right)$. We calculated $z$ scores using the Global Lung Function Initiative (GLI) reference equations (26).

\section{Risk Group Stratification}

We categorized survivors by risk: high risk for those having had pulmotoxic chemotherapy (bleomycin, busulfan, cardmustine, lomustine), HSCT, chest radiation (mediastinal/lung radiation, cranio-spinal radiation, and total body irradiation), and/or thoracic surgery (4), and 
standard risk for other cancer therapies. We further stratified high risk survivors into survivors with and without HSCT.

\section{Defining Covariates}

We assessed demographic characteristics at study entry and collected information on cancer diagnosis and treatment from medical records. Anthropometric measures were collected at the time of pulmonary function assessment as previously reported (20).

\section{Statistical Analysis}

Data were expressed in mean \pm standard deviation (SD) or median and interquartile range (IQR) as appropriate. Upper limits of normality (ULN) were defined as z score +1.64 for $L C l, F R C$, $\mathrm{S}_{\mathrm{COND}}$, and $\mathrm{S}_{\mathrm{ACIN}}$. Lower limits of normality (LLN) were defined as $z$ score -1.64 for $\mathrm{FEV}_{1}$ and FVC, and as $<0.7$ for $\mathrm{FEV}_{1} / \mathrm{FVC}(26)$. We used chi-squared and t-tests to compare demographic and clinical characteristics, and pulmonary function as appropriate in high vs standard risk survivors. With univariable and multivariable linear regression models, we investigated the association between pulmonary risk groups (high vs standard risk) and pulmonary function parameters, controlling for potential confounders. We adjusted for age, sex, weight, height, and active smoking status. In a sensitivity analysis, we added intervention group and time since diagnosis to the multivariable model to investigate the possible effects of increased physical activity or time since diagnosis on pulmonary function parameters. We used STATA software (Version 15.1, StataCorporation, Austin, TX). 


\section{Results}

\section{Study Population}

The SURfit study included 162 survivors overall, 46 of whom (28\%) were recruited for pulmonary function assessment. Complete characteristics of the assessed survivors are presented in Table 1, and the flowchart in Figure E1 illustrates the allocation of survivors into the high and standard risk groups. Among the assessed survivors, median age at diagnosis was 10 years (interquartile range [IQR] 4-14), median age at study 30 years (IQR 25-40), and median time since diagnosis 20 years (IQR 15-32). Over half of the survivors had been treated for leukemia and one-quarter for lymphoma, all but two survivors (96\%) had received chemotherapy, and half of the 46 assessed survivors had undergone radiotherapy. Seventeen of the assessed survivors (37\%) belonged to the high risk and $29(63 \%)$ to the standard risk group. In the high risk group, 15 survivors (88\%) had received chest radiation with a median cumulative dose of 20 Gray, nine survivors (53\%) received mediastinal/lung radiation, two survivors (12\%) cranio-spinal radiation, and four survivors (24\%) total body irradiation. The high and standard risk groups differed by age at diagnosis and by weight at lung function, and 11 high risk and 13 standard risk patients were in the physical intervention group. At the time of study, none of the survivors reported asthma or any other pre-existing pulmonary disease and none had chronic respiratory symptoms.

Table E1 (online supplement) compares the characteristics of all SURfit participants, with and without pulmonary function assessment. Survivors without pulmonary function assessment were younger at cancer diagnosis (median age 6 years), and a higher proportion in 
the assessment group had leukemia (25 of 46 survivors, 54\%) than did those in the group with no pulmonary function assessment (32 of 116, $28 \%$ ).

\section{$\mathrm{N}_{2}$ MBW Parameters}

After quality control, $\mathrm{N}_{2} \mathrm{MBW}$ indices were available for 15 of 17 high risk survivors (15 LCl and $15 \mathrm{~S}_{\mathrm{ACIN}}$ indices) and 26 of 29 standard risk survivors (26 LCl and $24 \mathrm{~S}_{\mathrm{ACIN}}$ indices) (Figure E1, online supplement). Overall, childhood cancer survivors had increased mean z scores for LCl, $\mathrm{FRC}$, and $\mathrm{S}_{\mathrm{ACIN}}$ compared to reference values, and high risk patients had higher $z$ scores than standard risk patients (Table 2). $\mathrm{N}_{2} \mathrm{MBW}$ indices tended to be increased as well in standard risk patients with mean $z$ scores of 0.95 for $\mathrm{LCl}, 0.20$ for FRC, and 0.65 for $\mathrm{S}_{\mathrm{ACIN}}$. Absolute $\mathrm{LCl}$ and $\mathrm{S}_{\mathrm{ACIN}}$ values (Figures 2 and 3) illustrate that a considerable proportion of high and standard risk patients had pulmonary function indices above the ULN.

$\mathrm{LCl}$ and $\mathrm{S}_{\mathrm{ACIN}}$ were abnormal in $60 \%$ (9 of 15 survivors) and $53 \%$ ( 8 of 15 survivors) of participants at high risk and in 23\% ( 6 of 26 survivors) and $21 \%$ ( 5 of 24 survivors) at standard risk ( $p<0.050$ ) (Table 3). $\mathrm{N}_{2} \mathrm{MBW}$ detected any abnormal value in $63 \%(26 / 41)$ of patients, $80 \%$ $(12 / 15)$ in the high risk and 54\% $(14 / 26)$ in the standard risk group ( $p=0.094)$.

\section{Spirometry Parameters}

After quality control, spirometry indices were available for 15 of 17 high risk survivors (15 FEV 1 and 15 FVC indices) and 23 of 29 standard risk survivors (23 FEV 1 and 23 FVC indices) (Figure E2, online supplement). Childhood cancer survivors overall and high risk survivors in particular had decreased mean $z$ scores for $\mathrm{FEV}_{1}$ (overall -0.43 , high risk -0.94) and FVC (overall -0.36, high risk 
-1.14) and preserved $\mathrm{FEV}_{1} / \mathrm{FVC}$ ratios (overall 0.07, high risk 0.36) (Table 2). Spirometry

parameters were normal in standard risk patients, with mean $z$ scores of -0.10 for $\mathrm{FEV}_{1}, 0.15$ for FVC, and -0.12 for $\mathrm{FEV}_{1} / \mathrm{FVC}$.

$\mathrm{FEV}_{1}$ and $\mathrm{FVC}$ were abnormal in $33 \%$ of participants in the high risk group and in $0 \%$ and $4 \%$ of participants in the standard risk group $(p<0.050)$ (Table 3$)$. As expected, standard risk survivors had a prevalence of abnormal spirometry comparable to the healthy reference population (5\% given a defined LLN of mean $z$ score -1.64$)$. Overall, spirometry detected less cases of pulmonary dysfunction than $\mathrm{N}_{2} \mathrm{MBW}$ with any abnormal parameter in $18 \%(7 / 38)$ of patients, $33 \%(5 / 15)$ in the high risk and $9 \%(2 / 23)$ in the standard risk group $(p=0.055)$. The proportion of participants who had both an abnormal spirometry and an abnormal $\mathrm{N}_{2} \mathrm{MBW}$ test was $n=4(24 \%)$ in the high risk group, and $n=1(4 \%)$ in the standard risk group.

\section{Association between Pulmotoxic Exposure and Pulmonary Function Parameters}

In a linear regression adjusting for the possible confounders sex, age, weight, height, and active smoking status at pulmonary function assessment, we investigated the change of lung function indices when comparing high risk vs standard risk (reference) survivors (Table E2, online supplement). $\mathrm{LCl}$ and $\mathrm{S}_{\mathrm{ACIN}}$ were higher in survivors exposed to pulmotoxic cancer treatment $\mathrm{LCl}$ by 1.110 units and $\mathrm{S}_{\mathrm{ACIN}}$ by 0.036 units. $\mathrm{FEV}_{1}$ and $\mathrm{FVC}$ were lower in survivors exposed to pulmotoxic cancer treatment $-\mathrm{FEV}_{1}$ by $0.239 \mathrm{~L}$ and $\mathrm{FVC}$ by $0.778 \mathrm{~L}$. The physical activity intervention had no apparent effect on pulmonary function parameters. We also observed no effect of time since diagnosis on pulmonary function parameters (data not shown). 


\section{Pulmonary Function Parameters in High Risk Survivors after HSCT}

Table E3 (online supplement) shows demographic and clinical characteristics, and pulmonary function abnormalities of the 17 high risk survivors, among whom five had undergone allogeneic HSCT. Four of these five HSCT survivors received total body irradiation with 12 Gray and one survivor received pulmotoxic chemotherapy with busulfan. Pulmonary function assessment was complete in four of the five HSCT survivors. All four HSCT survivors with available $\mathrm{N}_{2} \mathrm{MBW}$ results had at least one abnormal value, whereas only one had abnormal spirometry results (Table E3, online supplement). All four of these HSCT survivors had abnormal $\mathrm{S}_{\mathrm{ACIN}}$ parameters and two had abnormal LCl parameters, but only one had decreased $\mathrm{FEV}_{1}$ and FVC (Figures 2 and 3).

\section{Discussion}

$\mathrm{N}_{2} \mathrm{MBW}$ has to date been investigated only in pediatric cancer patients undergoing HSCT (14). This is the first study that shows results of $\mathrm{N}_{2} \mathrm{MBW}$ tests in long-term survivors of childhood cancer. We found that more than half of childhood cancer survivors had some signs of pulmonary dysfunction. $\mathrm{N}_{2}$-MBW detected more cases of abnormal pulmonary function than spirometry. $\mathrm{LCl}$ and $\mathrm{S}_{\mathrm{ACIN}}$ in particular were abnormal in patients considered to be at no increased risk because they had received chemotherapy other than busulfan, bleomycin, or nitrosoureas or radiotherapy other than to the chest.

Our results are in line with other studies suggesting that $\mathrm{N}_{2} \mathrm{MBW}$ might be a sensitive and complementary marker of pulmonary damage. A study of adult HSCT recipients from our 
group showed that LCl correlated well with increasing grades of chronic graft-versus-hostdisease (cGvHD), a pulmonary complication after HSCT (16). LCI and $\mathrm{S}_{\mathrm{ACIN}}$ were more sensitive than spirometry in detecting abnormal pulmonary function; $74 \%$ of patients had abnormal $\mathrm{LCl}$, but only $36 \%$ had abnormal $\mathrm{FEV}_{1}$. In the current study, $60 \%$ of high risk patients had abnormal $\mathrm{LCl}$ and $33 \%$ abnormal $\mathrm{FEV}_{1}$. A publication on lung transplant recipients reported that $\mathrm{LCl}$ increased with severity of bronchiolitis obliterans syndrome (27). A significant proportion of patients had abnormal $\mathrm{LCl}$ but not $\mathrm{FEV}_{1}$ values, which also suggests $\mathrm{LCl}$ to be more sensitive than spirometry in the early detection of pulmonary disease (27). In the only study that assessed $\mathrm{N}_{2} \mathrm{MBW}$ in pediatric $\mathrm{HSCT}$ recipients who were still under active cancer treatment (14), 28 children underwent pulmonary function assessment before and after HSCT. Again, LCI was a sensitive marker for CGvHD and was associated with persisting pulmonary symptoms, but $\mathrm{LCl}$ measured at HSCT was not predictive for the development of pulmonary CGvHD within one year after HSCT (14).

For spirometry indices, we identified only two studies that used the LLN to define abnormal spirometry as we did in our study and as recommended in the literature (26). In a Danish study of 94 leukemia survivors not exposed to pulmotoxic cancer treatment, with a median age at study of 16 years, abnormal $F E V_{1}, F V C$, and $\mathrm{FEV}_{1} / \mathrm{FVC}$ were observed in $8 \%, 15 \%$, and $1 \%$ of survivors compared to $0 \%, 4 \%$, and $4 \%$ in our standard risk group (22). In the other study of 41 Hodgkin and non-Hodgkin lymphoma survivors exposed to pulmotoxic cancer treatment, with a median age at study of 21 years, 27\%, 27\%, and $10 \%$ had abnormal FEV 1 , FVC, and $\mathrm{FEV}_{1} / \mathrm{FVC}$, which compares to $33 \%, 33 \%$, and $7 \%$ in our high risk patients (7). One additional study also used the LLN with a lower cut-off ( $z$ score -2.00) (28). All other studies that included 
abnormal spirometry indices used \%-predicted to define abnormality and results are therefore not directly comparable to our findings (Table E4, online supplement).

As the first study to investigate $\mathrm{N}_{2} \mathrm{MBW}$ in childhood cancer survivors, its strength derives from its standardized assessment of pulmonary function performed by a specialized, experienced pulmonary function laboratory. We included only high quality data after rigorous quality control, and technicians for pulmonary function assessment were blinded to the survivor's risk group. We collected detailed cancer treatment information for all patients.

One of the limitations of our study is that the study population was small and included a mix of different underlying diagnoses and pulmotoxic cancer treatments. However, the fact that we found some evidence for a benefit of $\mathrm{N}_{2} \mathrm{MBW}$ in this heterogeneous group is encouraging and should stimulate further studies including larger numbers of participants. The small number of participants in our study did not allow to study treatment modalities separately, and also limits the interpretation of the differences found between HSCT and noHSCT survivors. However, the fact that all HSCT survivors had abnormal $\mathrm{S}_{\mathrm{ACIN}}$ parameters is worthwhile noticing and may suggest that total body irradiation and intensive conditioning regimens may have caused alveolar damage. Replication of our results and refined assessment in larger studies are needed before the place of $\mathrm{N}_{2} \mathrm{MBW}$ in the clinical follow-up of childhood cancer survivors becomes clearer. Furthermore, we assessed pulmonary function only once in a cross-sectional fashion and did not have information on baseline pulmonary function before initiation of cancer treatment. Therefore, we cannot exclude preexisting preclinical pulmonary dysfunction. However, as survivors were asymptomatic and not aware of any pulmonary disease, this should not have substantially changed the results. Also the reference populations 
used for establishing normal values for lung function tests might contain subjects with subclinical disease, that has resulted neither in symptoms nor in a diagnosis. Longitudinal studies assessing pulmonary function before, during, and after treatment will be useful to investigate whether abnormal $\mathrm{N}_{2} \mathrm{MBW}$ indices predict future pulmonary morbidity and mortality in childhood cancer survivors. These studies should also measure diffusion capacity of the lungs for carbon monoxide (DLCO), which is another sensitive measure of early lung damage after chest radiation (28) and chemotherapy with bleomycin (29), but was not included in the current study. Further, there is no objective reference standard available, which represents early fibrotic changes in the lung, and against which we could assess performance of $\mathrm{N}_{2} \mathrm{MBW}$ and spirometry. $\mathrm{N}_{2} \mathrm{MBW}$ and spirometry are proxy measures for different anatomical abnormalities with $\mathrm{N}_{2} \mathrm{MBW}$ measuring ventilation homogeneity of the whole lung and spirometry primarily measuring obstruction of the larger, proximal airways. Therefore, conclusions on the superiority of either measure cannot be drawn at this stage. Finally, followup time since cancer diagnosis was variable in our participants; however, we found no association between the length of follow-up time and pulmonary function parameters.

Pulmotoxic cancer treatment leads to inflammatory and fibrotic changes of the small airways. While busulfan, bleomycin, and nitrosoureas are currently recognized as pulmotoxic chemotherapeutic agents, cyclophosphamide (6), methotrexate (9), and cisplatin $(5,6)$ also have been implicated in pulmonary damage. This is consistent with our finding that a considerable proportion of the standard risk group (48\%) had abnormal $\mathrm{N}_{2} \mathrm{MWB}$ results that suggest some damage to the small airways. 
Mortality due to pulmonary diseases following treatment for childhood cancer is particularly elevated (3). Yet early detection of pulmonary damage enables medical and lifestyle interventions that possibly improve pulmonary outcomes $(30,31)$. Our observation that spirometry was normal in standard risk patients stands in contrast to the pulmonary damage in half of this group that was suggested by $\mathrm{N}_{2} \mathrm{MBW}$. Because $\mathrm{N}_{2} \mathrm{MBW}$ also is a tidal breathing test, the administration of which can be largely independent of the age and clinical condition of patients, $\mathrm{N}_{2} \mathrm{MBW}$ can monitor pulmonary function during childhood.

We conclude that further study of childhood cancer survivors is needed, particularly longitudinal assessments, along with more sensitive surveillance of the pulmonary function of patients previously perceived as facing standard risk. Since $\mathrm{N}_{2} \mathrm{MBW}$ identified more cases of pulmonary dysfunction than spirometry, we believe $\mathrm{N}_{2} \mathrm{MBW}$ could be a complementary technique-for patients of all ages_for the screening of childhood cancer survivors for pulmonary damage.

\section{Acknowledgements}

We thank all childhood cancer survivors for participating in the SURfit study. We thank the study team of the SURfit study (Dr Iris Bänteli, Sandra Marti, Micha Zuercher) and Nicole Wellauer for performing the pulmonary function assessments. We thank the team of the Swiss Childhood Cancer Registry (Meltem Altun, Erika Brantschen, Katharina Flandera, Elisabeth Kiraly, Dr Verena Pfeiffer, Dr Shelagh Redmond, Julia Ruppel, Ursina Roder). We thank Dr Christopher Ritter for editorial assistance. 


\section{References}

1. Hudson MM, Ness KK, Gurney JG, Mulrooney DA, Chemaitilly W, Krull KR, et al. Clinical ascertainment of health outcomes among adults treated for childhood cancer. Jama. 2013;309(22):2371-81.

2. Armenian SH, Landier W, Francisco L, Herrera C, Mills G, Siyahian A, et al. Long-term pulmonary function in survivors of childhood cancer. J Clin Oncol. 2015;33(14):1592-600.

3. Schindler M, Spycher BD, Ammann RA, Ansari M, Michel G, Kuehni CE, et al. Cause-specific long-term mortality in survivors of childhood cancer in Switzerland: A population-based study. Int J Cancer. 2016;139(2):322-33.

4. Group CsO. Long-Term Follow-Up Guidelines for Survivors of Childhood, Adolescent, and Young Adult Cancers, Version 5.0 - October 20182018 [

5. Dietz AC, Chen Y, Yasui Y, Ness KK, Hagood JS, Chow EJ, et al. Risk and impact of pulmonary complications in survivors of childhood cancer: A report from the Childhood Cancer Survivor Study. Cancer. 2016;122(23):3687-96.

6. Mertens AC, Yasui Y, Liu Y, Stovall M, Hutchinson R, Ginsberg J, et al. Pulmonary complications in survivors of childhood and adolescent cancer. A report from the Childhood Cancer Survivor Study. Cancer. 2002;95(11):2431-41.

7. Nysom K, Holm K, Hertz H, Hesse B. Risk factors for reduced pulmonary function after malignant lymphoma in childhood. Medical and pediatric oncology. 1998;30(4):240-8.

8. Rossi SE, Erasmus JJ, McAdams HP, Sporn TA, Goodman PC. Pulmonary drug toxicity: radiologic and pathologic manifestations. Radiographics. 2000;20(5):1245-59.

9. Tantawy AAG, Elbarbary N, Ahmed A, Mohamed NA, Ezz-Elarab S. Pulmonary complications in survivors of childhood hematological malignancies: single-center experience. Pediatric hematology and oncology. 2011;28(5):403-17.

10. Inaba H, Yang J, Pan J, Stokes DC, Krasin MJ, Srinivasan A, et al. Pulmonary dysfunction in survivors of childhood hematologic malignancies after allogeneic hematopoietic stem cell transplantation. Cancer. 2010;116(8):2020-30.

11. Usemann J, Yammine S, Singer F, Latzin P. Inert gas washout: background and application in various lung diseases. Swiss medical weekly. 2017;147:w14483.

12. Aurora P, Stanojevic S, Wade A, Oliver C, Kozlowska W, Lum S, et al. Lung clearance index at 4 years predicts subsequent lung function in children with cystic fibrosis. American journal of respiratory and critical care medicine. 2011;183(6):752-8.

13. Stanojevic S, Davis SD, Retsch-Bogart G, Webster H, Davis M, Johnson RC, et al. Progression of Lung Disease in Preschool Patients with Cystic Fibrosis. American journal of respiratory and critical care medicine. 2017;195(9):1216-25. 
14. Uhlving HH, Skov L, Buchvald F, Heilmann C, Grell K, Ifversen M, et al. Lung clearance index for early detection of pulmonary complications after allo-HSCT in children. Pediatr Pulmonol. 2019;54(7):1029-38.

15. Nyilas S, Carlens J, Price T, Singer F, Muller C, Hansen G, et al. Multiple breath washout in pediatric patients after lung transplantation. American journal of transplantation : official journal of the American Society of Transplantation and the American Society of Transplant Surgeons. 2018;18(1):145-53.

16. Nyilas S, Baumeler L, Tamm M, Halter JP, Savic S, Korten I, et al. Inert Gas Washout in Bronchiolitis Obliterans Following Hematopoietic Cell Transplantation. Chest. 2018;154(1):157-68.

17. Limper AH. Chemotherapy-induced lung disease. Clinics in chest medicine. 2004;25(1):5364.

18. Hanania AN, Mainwaring W, Ghebre YT, Hanania NA, Ludwig M. Radiation-Induced Lung Injury: Assessment and Management. Chest. 2019;156(1):150-62.

19. Mulder RL, Thönissen NM, van der Pal HJ, Bresser P, Hanselaar W, Koning CC, et al. Pulmonary function impairment measured by pulmonary function tests in long-term survivors of childhood cancer. Thorax. 2011;66(12):1065-71.

20. Rueegg CS, Kriemler S, Zuercher SJ, Schindera C, Renner A, Hebestreit H, et al. A partially supervised physical activity program for adult and adolescent survivors of childhood cancer (SURfit): study design of a randomized controlled trial [NCT02730767]. BMC cancer. 2017;17(1):822.

21. Michel G, von der Weid NX, Zwahlen M, Adam M, Rebholz CE, Kuehni CE. The Swiss Childhood Cancer Registry: rationale, organisation and results for the years 2001-2005. Swiss medical weekly. 2007;137(35-36):502-9.

22. Nysom K, Holm K, Olsen JH, Hertz H, Hesse B. Pulmonary function after treatment for acute lymphoblastic leukaemia in childhood. British journal of cancer. 1998;78(1):21-7.

23. Robinson PD, Latzin P, Verbanck S, Hall GL, Horsley A, Gappa M, et al. Consensus statement for inert gas washout measurement using multiple- and single- breath tests. Eur Respir J. 2013;41(3):507-22.

24. Husemann K, Berg N, Engel J, Port J, Joppek C, Tao Z, et al. Double tracer gas single-breath washout: reproducibility in healthy subjects and COPD. Eur Respir J. 2014;44(5):1210-22.

25. Graham BL, Steenbruggen I, Miller MR, Barjaktarevic IZ, Cooper BG, Hall GL, et al. Standardization of Spirometry 2019 Update. An Official American Thoracic Society and European Respiratory Society Technical Statement. American journal of respiratory and critical care medicine. 2019;200(8):e70-e88.

26. Quanjer PH, Stanojevic S, Cole TJ, Baur X, Hall GL, Culver BH, et al. Multi-ethnic reference values for spirometry for the 3-95-yr age range: the global lung function 2012 equations. Eur Respir J. 2012;40(6):1324-43. 
27. Driskel M, Horsley A, Fretwell L, Clayton N, Al-Aloul M. Lung clearance index in detection of post-transplant bronchiolitis obliterans syndrome. ERJ Open Res. 2019;5(4).

28. Weiner DJ, Maity A, Carlson CA, Ginsberg JP. Pulmonary function abnormalities in children treated with whole lung irradiation. Pediatric blood \& cancer. 2006;46(2):222-7.

29. De A, Guryev I, LaRiviere A, Kato R, Wee CP, Mascarenhas L, et al. Pulmonary function abnormalities in childhood cancer survivors treated with bleomycin. Pediatric blood \& cancer. 2014;61(9):1679-84.

30. Williams KM, Cheng GS, Pusic I, Jagasia M, Burns L, Ho VT, et al. Fluticasone, Azithromycin, and Montelukast Treatment for New-Onset Bronchiolitis Obliterans Syndrome after Hematopoietic Cell Transplantation. Biology of blood and marrow transplantation : journal of the American Society for Blood and Marrow Transplantation. 2016;22(4):710-6.

31. Flaherty KR, Wells AU, Cottin V, Devaraj A, Walsh SLF, Inoue Y, et al. Nintedanib in Progressive Fibrosing Interstitial Lung Diseases. The New England journal of medicine. 2019;381(18):1718-27. 
Table 1. Characteristics of childhood cancer survivors participating in the SURfit study and undergoing a pulmonary function assessment

\begin{tabular}{|c|c|c|c|c|}
\hline & $\begin{array}{l}\text { Total } \\
\mathrm{N}=46(100 \%)^{*}\end{array}$ & $\begin{array}{l}\text { High risk }^{\dagger} \\
\mathrm{N}=17(37 \%)^{*}\end{array}$ & $\begin{array}{l}\text { Standard risk }^{\ddagger} \\
\mathrm{N}=29(63 \%)^{*}\end{array}$ & $p^{\S}$ \\
\hline $\begin{array}{l}\text { Demographic characteristics } \\
\text { Male sex } \\
\text { Age at study, median [IQR], years }\end{array}$ & $\begin{array}{c}24(52 \%) \\
30[25-40]\end{array}$ & $\begin{array}{c}9(53 \%) \\
31[22-36]\end{array}$ & $\begin{array}{c}15(52 \%) \\
28[25-41]\end{array}$ & $\begin{array}{l}0.936 \\
0.559\end{array}$ \\
\hline $\begin{array}{l}\text { Clinical characteristics } \\
\text { Age at diagnosis, median [IQR], years } \\
\text { Time since diagnosis, median [IQR], } \\
\text { years } \\
\text { Weight at study, median [IQR], kg } \\
\text { Height at study, median [IQR], cm } \\
\text { Active smoking } \\
\text { ICCC-3 cancer diagnosis } \\
\text { I Leukemia } \\
\text { II Lymphoma } \\
\text { III CNS tumor } \\
\text { IV Neuroblastoma } \\
\text { V Retinoblastoma } \\
\text { VIII Bone tumor } \\
\text { IX Soft tissue sarcoma } \\
\text { XIII LCH }\end{array}$ & $\begin{array}{c}10[4-14] \\
20[15-32] \\
68[60-78] \\
169[163-177] \\
10(22 \%) \\
25(54 \%) \\
11(24 \%) \\
2(4 \%) \\
1(2 \%) \\
1(2 \%) \\
4(9 \%) \\
1(2 \%) \\
1(2 \%)\end{array}$ & $\begin{array}{c}12[9-14] \\
18[13-25] \\
64[52-71] \\
174[161-179] \\
2(12 \%) \\
6(35 \%) \\
8(47 \%) \\
1(6 \%) \\
0(0 \%) \\
0(0 \%) \\
2(13 \%) \\
0(0 \%) \\
0(0 \%)\end{array}$ & $\begin{array}{c}6[4-12] \\
24[18-32] \\
74[62-79] \\
168[163-174] \\
8(28 \%) \\
19(66 \%) \\
3(10 \%) \\
1(4 \%) \\
1(4 \%) \\
1(4 \%) \\
2(7 \%) \\
1(3 \%) \\
1(4 \%)\end{array}$ & $\begin{array}{l}0.083 \\
0.029 \\
0.851 \\
0.209\end{array}$ \\
\hline History of relapse & $2(4 \%)$ & $1(12 \%)$ & $1(4 \%)$ & 0.130 \\
\hline $\begin{array}{l}\text { Any chemotherapy } \\
\text { Any radiotherapy }\end{array}$ & $\begin{array}{l}44(96 \%) \\
23(50 \%)\end{array}$ & $\begin{array}{c}17(100 \%) \\
15(88 \%)\end{array}$ & $\begin{array}{l}27(93 \%) \\
8(28 \%)\end{array}$ & $\begin{array}{c}0.237 \\
<0.001\end{array}$ \\
\hline Chest radiation"I & $15(33 \%)$ & $15(88 \%)$ & $0(0 \%)$ & $<0.001$ \\
\hline $\begin{array}{c}\text { Median, [IQR], Gray } \\
\text { Mediastinal/lung radiation }\end{array}$ & $\begin{array}{c}20[12-35] \\
9(20 \%)\end{array}$ & $\begin{array}{c}20[12-35] \\
9(53 \%)\end{array}$ & $\begin{array}{c}\text { NA } \\
0(0 \%)\end{array}$ & $\begin{array}{c}\text { NA } \\
<0.001\end{array}$ \\
\hline Median, [IQR], Gray & 27 [20-39] & 27 [20-39] & NA & NA \\
\hline $\begin{array}{l}\text { Cranio-spinal radiation } \\
\text { Median, [IQR], Gray }\end{array}$ & $\begin{array}{c}2(4 \%) \\
22[20-23]\end{array}$ & $\begin{array}{c}2(12 \%) \\
22[20-23]\end{array}$ & $\begin{array}{l}0(0 \%) \\
\text { NA }\end{array}$ & $\begin{array}{c}0.059 \\
\text { NA }\end{array}$ \\
\hline Total body irradiation & $4(9 \%)$ & $4(24 \%)$ & $0(0 \%)$ & 0.059 \\
\hline $\begin{array}{l}\text { Median, [IQR], Gray } \\
\mathrm{HSCT}\end{array}$ & $\begin{array}{c}12[12-12] \\
5(11 \%)\end{array}$ & $\begin{array}{c}12[12-12] \\
5(29 \%)\end{array}$ & $\begin{array}{l}\text { NA } \\
0(0 \%)\end{array}$ & $\begin{array}{c}\text { NA } \\
0.002\end{array}$ \\
\hline
\end{tabular}

Abbreviations: CNS, central nervous system; IQR, interquartile range; $N$, number; $\mathrm{HSCT}$, hematopoietic stem cell transplantation; LCH, Langerhans cell histiocytosis; ICCC-3, International Classification of Childhood Cancer, 3rd edition

${ }^{*}$ Column percentages are given

${ }^{\dagger}$ High risk = pulmotoxic cancer treatment including busulfan, bleomycin, nitrosureas, chest radiation, thoracic surgery, HSCT

* Standard risk = no pulmotoxic cancer treatment

$\S$ P-values comparing high risk and standard risk patients calculated from chi-squared tests for categorical variables and from t-tests for continuous variables

II Including mediastinal/lung radiation, cranio-spinal radiation, and total body irradiation 
Table 2. $\mathrm{N}_{2} \mathrm{MBW}\left(\mathrm{LCl}, \mathrm{FRC}, \mathrm{S}_{\mathrm{COND}}, \mathrm{S}_{\mathrm{ACIN}}\right)$ and spirometry $\left(\mathrm{FEV}_{1}, \mathrm{FVC}, \mathrm{FEV}_{1} / \mathrm{FVC}\right)$ indices in childhood cancer survivors, median age 30 years $(\mathrm{N}=46)$

\begin{tabular}{|c|c|c|c|c|c|}
\hline & $\begin{array}{c}\text { Reference } \\
\text { population* }\end{array}$ & $\begin{array}{l}\text { Total } \\
\mathrm{N}=46\end{array}$ & High risk $+\mathrm{N}=17$ & $\begin{array}{c}\text { Standard risk } \ddagger \\
N=29\end{array}$ & $P \S$ \\
\hline \multicolumn{6}{|l|}{$\mathrm{N}_{2} \mathrm{MBW}||$} \\
\hline mean (SD) & $6.94(0.61)$ & $7.77(1.64)$ & $8.22(1.46)$ & $7.52(1.71)$ & 0.195 \\
\hline z score, mean (SD) & NA & $1.37(2.69)$ & 2.09 (2.39) & $0.95(2.81)$ & \\
\hline \multicolumn{6}{|l|}{ FRC L } \\
\hline mean (SD) & $3.21(0.81)$ & $3.38(1.10)$ & $3.38(1.13)$ & $3.38(1.10)$ & 0.998 \\
\hline z score, mean (SD) & NA & $0.21(1.35)$ & $0.21(1.39)$ & $0.20(1.36)$ & \\
\hline \multicolumn{6}{|l|}{$\mathrm{S}_{\text {COND }}$} \\
\hline mean (SD) & $0.028(0.026)$ & $0.018(0.016)$ & $0.017(0.013)$ & $0.018(0.0170)$ & 0.782 \\
\hline z score, mean (SD) & NA & $-0.40(0.60)$ & $-0.44(0.51)$ & $-0.38(0.65)$ & \\
\hline \multicolumn{6}{|l|}{$S_{\text {ACIN }}$} \\
\hline mean (SD) & $0.058(0.028)$ & $0.095(0.090)$ & $0.127(0.092)$ & $0.076(0.078)$ & 0.076 \\
\hline z score, mean (SD) & NA & $1.34(3.08)$ & $2.45(3.29)$ & $0.65(2.79)$ & \\
\hline \multicolumn{6}{|l|}{ Spirometryף } \\
\hline \multicolumn{6}{|l|}{ FEV $_{1}$} \\
\hline mean (SD) & 4.46 & $3.57(0.83)$ & $3.38(1.00)$ & $3.70(0.69)$ & 0.247 \\
\hline z score, mean (SD) & NA & $-0.43(1.26)$ & $-0.94(1.39)$ & $-0.10(1.07)$ & \\
\hline \multicolumn{6}{|l|}{ FVCL } \\
\hline mean (SD) & 5.32 & $4.35(1.12)$ & $3.98(1.10)$ & 4.59 (1.09) & 0.101 \\
\hline z score, mean (SD) & NA & $-0.36(1.58)$ & $-1.14(1.23)$ & $0.15(1.61)$ & \\
\hline \multicolumn{6}{|l|}{$\mathrm{FEV}_{1} / \mathrm{FVC}$} \\
\hline mean (SD) & 0.85 & $0.83(0.09)$ & $0.85(0.08)$ & $0.82(0.10)$ & 0.305 \\
\hline z score mean (SD) & NA & $0.07(1.24)$ & $0.36(1.14)$ & $-0.12(1.29)$ & \\
\hline
\end{tabular}

Abbreviations: $F R C$, functional residual capacity; $\mathrm{FEV}_{1}$, forced expiratory volume in 1 second; $F V C$, forced vital capacity; $\mathrm{HSCT}$, hematopoietic stem cell transplantation; $\mathrm{LCl}$, lung clearance index; $\mathrm{NA}$, not applicable; $\mathrm{N}_{2} \mathrm{MBW}$, nitrogen multiple-breath washout; $N$, number; $S D$, standard deviation; $S_{A C I N}$, acinar ventilation inhomogeneity index; $\mathrm{S}_{\mathrm{COND}}$, conductive ventilation inhomogeneity index

* Expected mean values from published reference populations: Husemann, Eur Respir J, 2014 (21) for $\mathrm{N}_{2} \mathrm{MBW}$; Quanjer, Eur Respir J, 2012 (22) for spirometry

† High risk = pulmotoxic cancer treatment including busulfan, bleomycin, nitrosureas, chest radiation, thoracic surgery, HSCT

¥ Standard risk = no pulmotoxic cancer treatment

$\S$ P-values comparing high and standard risk patients calculated from t-tests

II $\mathrm{N}_{2} \mathrm{MBW}$ indices included after quality check; total survivors: $41 \mathrm{~N}_{2} \mathrm{MBW}\left(41 \mathrm{LCl}, 39 \mathrm{~S}_{\mathrm{ACIN}}\right)$, high risk survivors: 15 $\mathrm{N}_{2} \mathrm{MBW}\left(15 \mathrm{LCl}, 15 \mathrm{~S}_{\mathrm{ACIN}}\right)$, standard risk survivors: $26 \mathrm{~N}_{2} \mathrm{MBW}\left(26 \mathrm{LCl}, 24 \mathrm{~S}_{\mathrm{ACIN}}\right)$; see also Figure E1 If Spirometry indices included after quality check; total survivors: 38 spirometry ( $38 \mathrm{FEV}_{1}, 38 \mathrm{FVC}$ ), high risk survivors: 15 spirometry ( $15 \mathrm{FEV}_{1}, 15 \mathrm{FVC}$ ), standard risk survivors: 23 spirometry ( $23 \mathrm{FEV}_{1}, 23 \mathrm{FVC}$ ); see also Figure E1 
Table 3. Prevalence of abnormal $\mathrm{N}_{2} \mathrm{MWB}$ parameters (above the upper limit of normality) and spirometry parameters (below the lower limit of normality) in 46 childhood cancer survivors, median age 30 years, stratified into high and standard risk for pulmonary dysfunction

\begin{tabular}{|c|c|c|c|c|c|}
\hline & $\begin{array}{c}\text { Reference } \\
\text { population* }\end{array}$ & $\begin{array}{l}\text { Total } \\
N=46\end{array}$ & $\begin{array}{l}\text { High risk }{ }^{\dagger} \\
\qquad N=17\end{array}$ & $\begin{array}{l}\text { Standard risk } \ddagger \\
\qquad N=29\end{array}$ & $\mathrm{P} \S$ \\
\hline \multicolumn{6}{|l|}{$\mathbf{N}_{2} \mathbf{M B W}||$} \\
\hline LCI, ULN & $5 \%$ & $15 / 41(37 \%)$ & $9 / 15(60 \%)$ & $6 / 26(23 \%)$ & 0.018 \\
\hline FRC L, ULN & $5 \%$ & $6 / 41(15 \%)$ & $2 / 15(13 \%)$ & $4 / 26(15 \%)$ & 0.858 \\
\hline $\mathrm{S}_{\text {COND }} \mathrm{L}^{-1}, \mathrm{ULN}$ & $5 \%$ & $0 / 39(0 \%)$ & $0 / 14(0 \%)$ & $0 / 25(0 \%)$ & NA \\
\hline $\mathrm{S}_{\mathrm{ACIN}} \mathrm{L}^{-1}, \mathrm{ULN}$ & $5 \%$ & $13 / 39(33 \%)$ & $8 / 15(53 \%)$ & $5 / 24(21 \%)$ & 0.036 \\
\hline Any abnormal $\mathrm{N}_{2} \mathrm{MBW}$ value & NA & $26 / 41(63 \%)$ & $12 / 15(80 \%)$ & $14 / 26(54 \%)$ & 0.094 \\
\hline \multicolumn{6}{|l|}{ Spirometry ๆ } \\
\hline $\mathrm{FEV}_{1}, \mathrm{LLN}$ & $5 \%$ & $5 / 38(13 \%)$ & $5 / 15(33 \%)$ & $0 / 23(0 \%)$ & 0.003 \\
\hline FVC L, LLN & $5 \%$ & $6 / 38(16 \%)$ & $5 / 15(33 \%)$ & $1 / 23(4 \%)$ & 0.017 \\
\hline $\mathrm{FEV}_{1} / \mathrm{FVC}, \mathrm{LLN}$ & $5 \%$ & $2 / 38(5 \%)$ & $1 / 15(7 \%)$ & $1 / 23(4 \%)$ & 0.754 \\
\hline Any abnormal spirometry value & NA & $7 / 38(18 \%)$ & $5 / 15(33 \%)$ & $2 / 23(9 \%)$ & 0.055 \\
\hline
\end{tabular}

Abbreviations: $\mathrm{LCl}$, lung clearance index; $\mathrm{FEV}_{1}$, forced expiratory volume in 1 second; $\mathrm{FVC}$, forced vital capacity; FRC, functional residual capacity; LLN, lower limit of normality; N, number; NA, not applicable; $\mathrm{N}_{2} \mathrm{MBW}$, nitrogen multiple-breath washout; $S_{A C I N}$, acinar ventilation inhomogeneity index; $S_{C O N D}$, conductive ventilation inhomogeneity index; ULN, upper limit of normality

\footnotetext{
* Expected prevalence of abnormal pulmonary function parameters based on definitions of ULN $=z$ score +1.64 (for $\mathrm{N}_{2} \mathrm{MBW}$ ) and LLN = $z$ score -1.64 (for $\mathrm{FEV}_{1}$ and FVC) and $<0.7$ for $\mathrm{FEV}_{1} / \mathrm{FEV}$

+ High risk = pulmotoxic cancer treatment including busulfan, bleomycin, nitrosoureas, chest radiation, thoracic surgery, HSCT

¥Standard risk = no pulmotoxic cancer treatment

$\S \mathrm{P}$-values comparing high and standard risk patients calculated from chi-squared tests

II Included $\mathrm{N}_{2} \mathrm{MBW}$ indices after quality check; total survivors: $41 \mathrm{~N}_{2} \mathrm{MBW}\left(41 \mathrm{LCl}, 39 \mathrm{~S}_{\mathrm{ACIN}}\right)$, high risk survivors: 15 $\mathrm{N}_{2} \mathrm{MBW}\left(15 \mathrm{LCl}, 15 \mathrm{~S}_{\mathrm{ACIN}}\right)$, standard risk survivors: $26 \mathrm{~N}_{2} \mathrm{MBW}\left(26 \mathrm{LCl}, 24 \mathrm{~S}_{\mathrm{ACIN}}\right)$

II Included spirometry indices after quality check; total survivors: 38 spirometry ( $38 \mathrm{FEV}_{1}, 38 \mathrm{FVC}$ ), high risk survivors: 15 spirometry ( $15 \mathrm{FEV}_{1}, 15 \mathrm{FVC}$ ), standard risk survivors: 23 spirometry ( $23 \mathrm{FEV}_{1}, 23 \mathrm{FVC}$ )
} 


\section{Figure Legends}

Figure 1: Model of pathophysiological mechanisms underlying pulmotoxic effects of cancer therapy and relationship with lung function outcome measures. The white boxes describe mechanisms of cancer-treatment-related lung injury. Ionizing radiation from chest radiation, chemotherapy, and hematopoietic stem cell transplantation induce release of oxygen radicals, cause vascular damage, and promote inflammation in the lung. Persistent inflammation results in pathological changes in the alveolar, vascular endothelial, and parenchymal departments, which is associated with pathologic immune cell infiltration, capillary permeability, and pulmonary edema. The lung damage may be acute and reversible-presenting as pneumonitis, or chronic and irreversible-presenting as pulmonary fibrosis. The shaded boxes describe the outcome measures described in different types of lung function tests. The box framed with continuous lines describe lung function parameters assessed in previous studies and in this study; boxes framed in dashed line represents outcomes assessed in previous studies but not in this study; the box framed with a pointed line describes outcomes assessed only in this study. Abbreviations: DLCO, diffusing capacity of the lung for carbon monoxide; HSCT, hematopoietic stem cell transplantation; $\mathrm{N}_{2} \mathrm{MBW}$, nitrogen multiple-breath washout.

Figure 2. $\mathrm{LCl}$ in 46 adult childhood cancer survivors stratified into high risk - with and without HSCT - and standard risk for pulmonary dysfunction. Dashed blue line $=$ ULN $=7.94(21)$ Abbreviations: HSCT, hematopoietic stem cell transplantation; LCI, lung clearance index; ULN, upper limit of normality. 
Figure 3. $\mathrm{S}_{\mathrm{ACIN}}$ in 46 adult childhood cancer survivors stratified into high risk, with and without $\mathrm{HSCT}$, and standard risk for pulmonary dysfunction. Dashed blue line $=U L N=0.10(21)$ Abbreviations: $\mathrm{HSCT}$, hematopoietic stem cell transplantation; $\mathrm{S}_{\mathrm{ACIN}}$, acinar ventilation inhomogeneity index; ULN, upper limit of normality. 


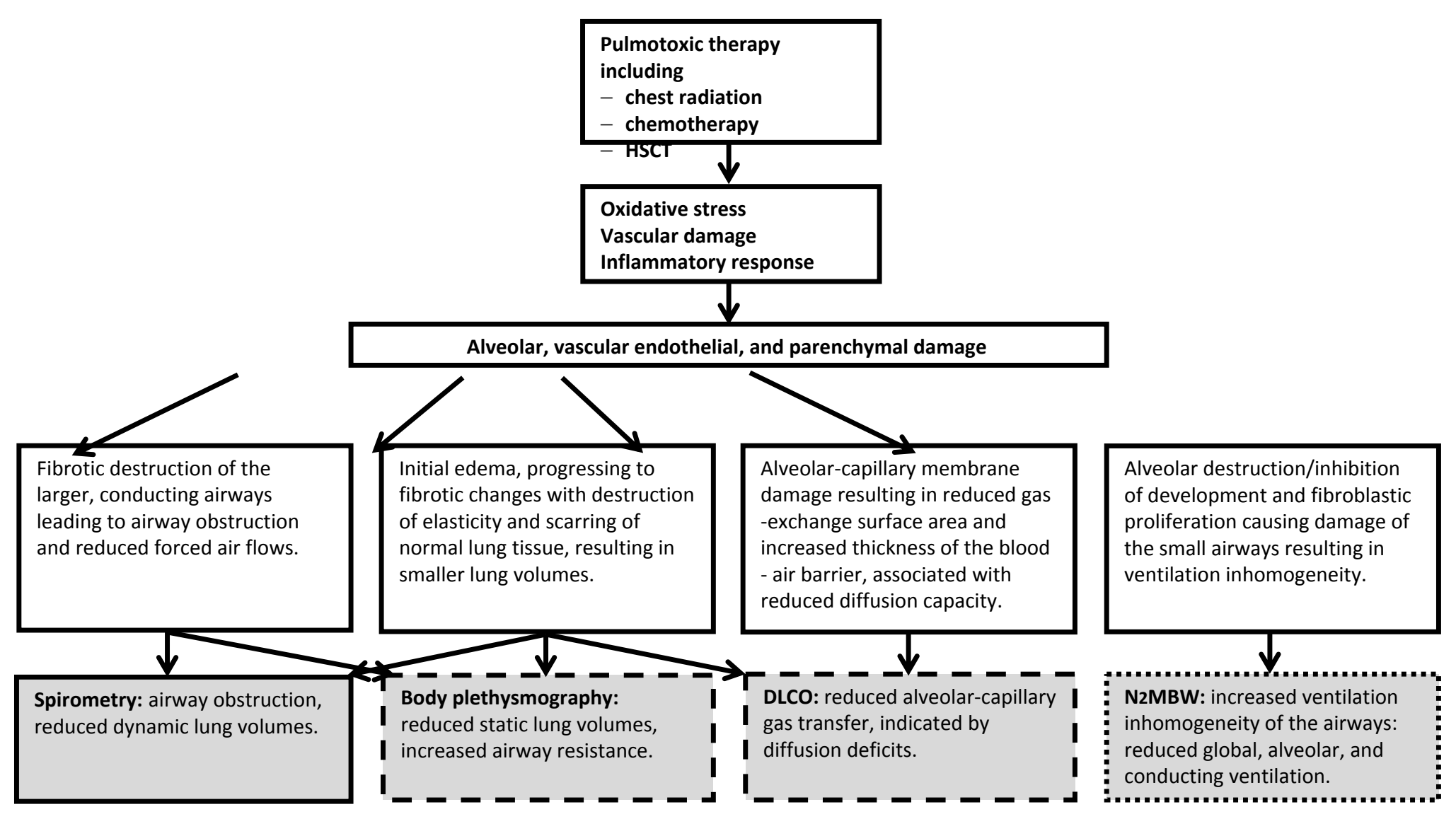




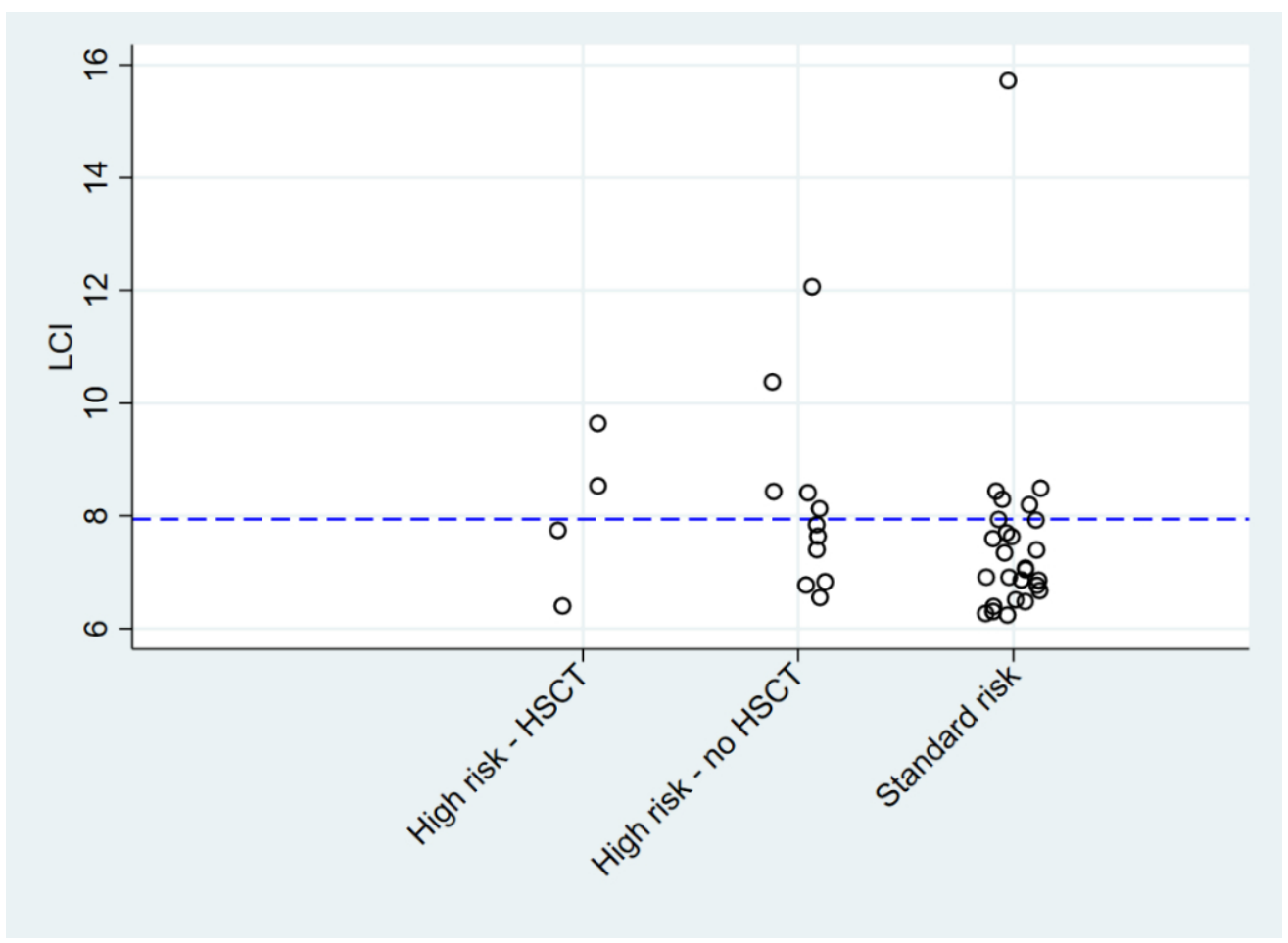

Figure 2. LCI in 46 adult childhood cancer survivors stratified into high risk - with and without HSCT - and standard risk for pulmonary dysfunction. Dashed blue line $=U L N=7.94$ (21)

Abbreviations: HSCT, hematopoietic stem cell transplantation; LCI, lung clearance index; ULN, upper limit of normality

$121 \times 88 \mathrm{~mm}(220 \times 220 \mathrm{DPI})$ 


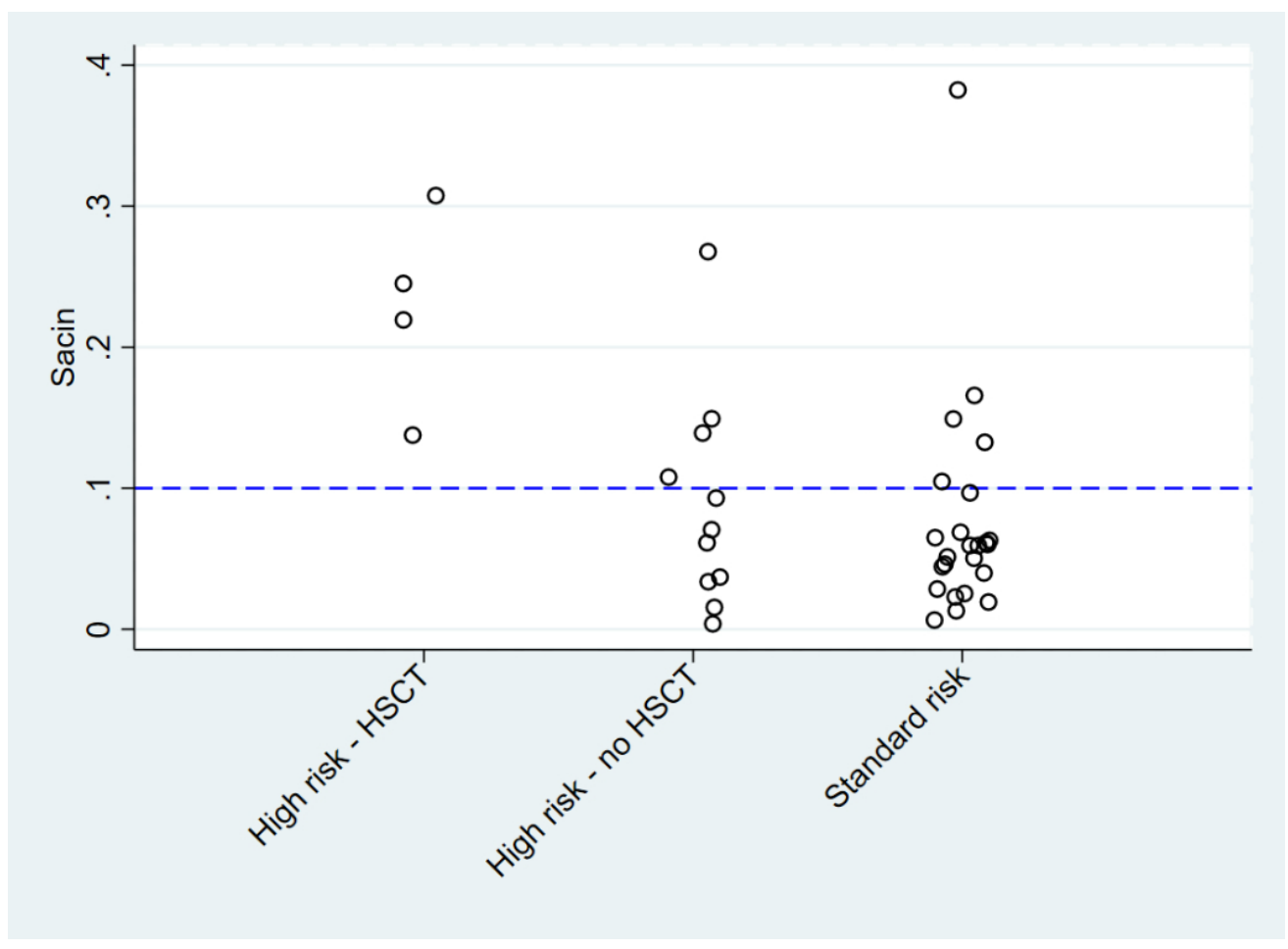

Figure 3. SACIN in 46 adult childhood cancer survivors stratified into high risk, with and without HSCT, and standard risk for pulmonary dysfunction. Dashed blue line $=U L N=0.10(21)$

Abbreviations: HSCT, hematopoietic stem cell transplantation; SACIN, acinar ventilation inhomogeneity index; ULN, upper limit of normality

$122 \times 88 \mathrm{~mm}(220 \times 220 \mathrm{DPI})$ 


\section{Online Supplement}

Pulmonary dysfunction after treatment for childhood cancer: Comparing multiplebreath washout with spirometry

Christina Schindera, MD, Jakob Usemann, MD, PhD, Simeon Joel Zuercher, PhD, Ruedi Jung, MSc, Rahel Kasteler, MD, PhD, Bettina Frauchiger, MD, Geraldine Naumann, Corina Silvia Rueegg, PhD, Philipp Latzin, MD, PhD, Claudia Elisabeth Kuehni, MD, Nicolas Xavier von der Weid, MD 
Table E1. Characteristics of childhood cancer survivors participating in the SURfit study stratified into pulmonary assessment and no pulmonary function assessment

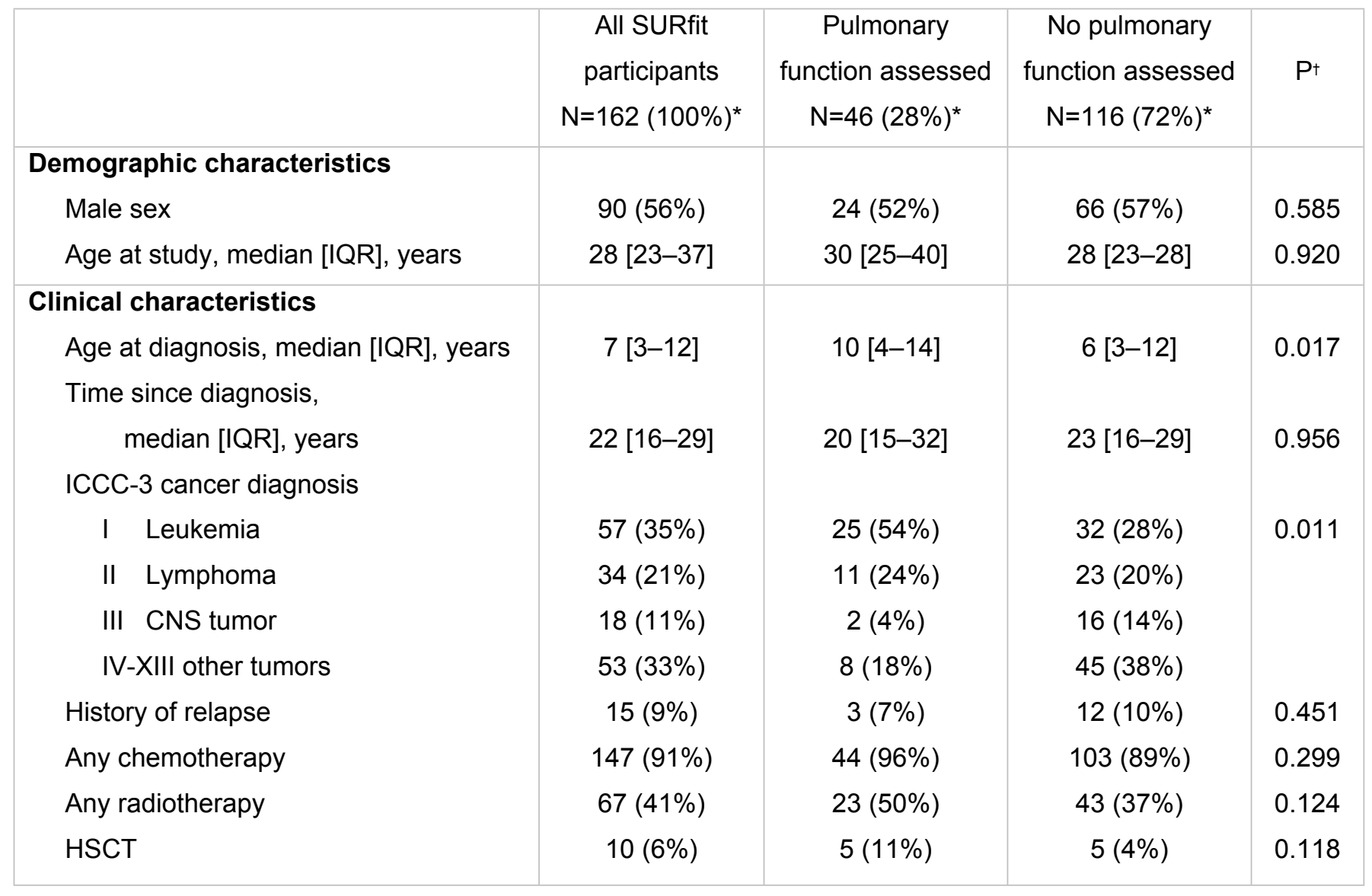

Abbreviations: CNS, central nervous system; ICCC-3, International Classification of Childhood Cancer, 3rd edition; IQR, interquartile range; N, number; HSCT, hematopoietic stem cell transplantation

* Column percentages are given

${ }^{\dagger} \mathrm{P}$-values comparing survivors with and without pulmonary function assessment calculated from chisquared tests for categorical variables and from t-tests for continuous variables 
Table E2. Association between risk group and pulmonary function parameters $\left(\mathrm{N}_{2}-\mathrm{MBW}\right.$ and spirometry) in 46 adult childhood cancer survivors, median age 30 years at study. Results from univariable (Model 1) and multivariable linear regression adjusting for age, sex, weight, height and active smoking (Model 2)

\begin{tabular}{|c|c|c|}
\hline & $\begin{array}{c}\text { Model } 1 \\
\text { Univariable linear regression }\end{array}$ & $\begin{array}{c}\text { Model } 2 \\
\text { Multivariable linear regression } \\
\text { adjusted for age, sex, weight, height } \\
\text { and smoking }\end{array}$ \\
\hline & $\beta$ coefficient $^{*}(95 \% \mathrm{Cl}), \mathrm{p}$-value & $\beta$ coefficient $^{*}(95 \% \mathrm{Cl}), p$-value \\
\hline \multicolumn{3}{|l|}{ N2-MBW } \\
\hline LCl, mean & $0.695(-0.371-1.760), p=0.195$ & $1.110(-0.188-2.398), p=0.092$ \\
\hline FRC L, mean & $0.001(-0.727-0.729, p=0.998$ & $-0.253(-0.816-0.612), p=0.420$ \\
\hline $\mathrm{S}_{\mathrm{COND}} \mathrm{L}^{-1}$, mean & $-0.002(-0.012-0.009), p=0.782$ & $0.004(-0.009-0.016), p=0.548$ \\
\hline$S_{A C I N} L^{-1}$, mean & $0.050(-0.005-0.106), p=0.076$ & $0.036(-0.032-0.103), p=0.292$ \\
\hline \multicolumn{3}{|l|}{ Spirometry } \\
\hline FEV1, mean & $-0.323(-0.878-0.233), p=247$ & $-0.239(-0.704-0.226), p=0.303$ \\
\hline FVC L, mean & $-0.610(-1.34-0.124), p=0.101$ & $-0.778(-1.400--0.157), p=0.016$ \\
\hline FEV1/FVC, mean & $0.032(-0.030-0.094), p=0.305$ & $0.066(-0.005-0.137), p=0.066$ \\
\hline
\end{tabular}

Abbreviations: $\mathrm{LCl}$, lung clearance index; $\mathrm{FEV}_{1}$, forced expiratory volume in 1 second; $\mathrm{FVC}$, forced vital capacity; FRC, functional residual capacity; LLN, lower limit of normal; N, number; NA, not applicable; $\mathrm{N}_{2}-\mathrm{MBW}$, nitrogen multiple-breath washout; $\mathrm{S}_{\mathrm{ACIN}}$, acinar ventilation inhomogeneity index;

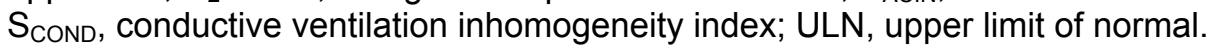

* The $\beta$ coefficient is the degree of change in the N2-MBW and spirometry parameters for high risk patients compared to low risk patients (reference). 
Table E3. Characteristics and pulmonary function test results of the 17 high risk survivors undergoing pulmonary function testing

\begin{tabular}{|c|c|c|c|c|c|c|c|c|c|c|c|}
\hline $\begin{array}{l}\text { High risk } \\
\text { survivors }\end{array}$ & Sex & $\begin{array}{l}\text { Age, } \\
\text { years }\end{array}$ & $\begin{array}{l}\text { Childhood cancer } \\
\text { diagnosis }\end{array}$ & HSCT & $\begin{array}{l}\text { Chest radiation } \\
\text { dose }\end{array}$ & $\begin{array}{l}\text { Pulmotoxic } \\
\text { chemotherapy }\end{array}$ & $\begin{array}{l}\text { Abnormal } \\
\text { LCl }\end{array}$ & $\begin{array}{l}\text { Abnormal } \\
S_{\text {ACIN }}\end{array}$ & $\begin{array}{l}\text { Abnormal } \\
\text { FEV }_{1}\end{array}$ & $\begin{array}{l}\text { Abnormal } \\
\text { FVC }\end{array}$ & $\begin{array}{l}\text { Any } \\
\text { abnormality }\end{array}$ \\
\hline 1 & $F$ & $21-25$ & Hodgkin & No & $20 \mathrm{~Gy}$ & - & No & Yes & Yes & Yes & Yes \\
\hline 2 & $F$ & $<21$ & Ewing sarcoma & No & $45 \mathrm{~Gy}$ & - & Yes & Yes & Yes & Yes & Yes \\
\hline 3 & $F$ & $36-40$ & Hodgkin & No & $20 \mathrm{~Gy}$ & - & No & No & No & No & No \\
\hline 4 & $\mathrm{M}$ & $46-50$ & Hodgkin & No & 27 Gy & - & Yes & Yes & No & No & Yes \\
\hline 5 & $F$ & $21-25$ & Ewing & No & 54 Gy & - & NA & NA & No & No & No \\
\hline 6 & $\mathrm{~F}$ & $31-35$ & ALL & No & $20 \mathrm{~Gy}$ & - & No & No & No & No & No \\
\hline 7 & $\mathrm{M}$ & $31-35$ & Hodgkin & No & $20 \mathrm{~Gy}$ & - & Yes & Yes & No & No & Yes \\
\hline 8 & $\mathrm{~F}$ & $21-25$ & Hodgkin & No & $20 \mathrm{~Gy}$ & - & Yes & No & No & No & Yes \\
\hline 9 & $F$ & $21-25$ & Hodgkin & No & 35 Gy & - & Yes & No & NA & NA & Yes \\
\hline 10 & $M$ & $36-40$ & Hodgkin & No & - & Bleomycin & No & No & No & No & No \\
\hline 11 & $\mathrm{M}$ & $46-50$ & T-NHL & No & 39 Gy & - & Yes & No & Yes & Yes & Yes \\
\hline 12 & $\mathrm{M}$ & $26-30$ & Medulloblastoma & No & $23 \mathrm{~Gy}$ & - & Yes & No & Yes & Yes & Yes \\
\hline 13 & $M$ & $21-25$ & CML & Yes & $12 \mathrm{~Gy}$ & - & No & Yes & NA & NA & Yes \\
\hline 14 & $\mathrm{~F}$ & $31-35$ & CML & Yes & $12 \mathrm{~Gy}$ & - & NA & NA & Yes & Yes & Yes \\
\hline 15 & $\mathrm{M}$ & $41-45$ & ALL & Yes & $12 \mathrm{~Gy}$ & - & No & Yes & No & No & Yes \\
\hline 16 & $\mathrm{M}$ & $31-35$ & AML & Yes & $12 \mathrm{~Gy}$ & - & Yes & Yes & No & No & Yes \\
\hline 17 & $M$ & $21-25$ & MDS & Yes & - & Busulfan & Yes & Yes & No & No & Yes \\
\hline
\end{tabular}

Abbreviations: ALL, acute lymphoblastic leukemia, AML, acute myeloid leukemia; $C M L$, chronic myeloid leukemia; $F$, female; FEV 1 , forced expiratory volume in 1 second; FVC, forced vital capacity; HSCT, hematopoietic stem cell transplantation; Gy, gray; LCI, Lung clearance index; M, male; N, number; NA, not applicable/assessed; $\mathrm{S}_{\mathrm{ACIN}}$, acinar ventilation inhomogeneity index; MDS, myelodysplastic syndrome; T-NHL, T-non-Hodgkin lymphoma 
Table E4. Studies on pulmonary function testing in childhood cancer survivors including the prevalence of individual abnormal spirometry indices

\begin{tabular}{|c|c|c|c|c|c|c|c|c|c|}
\hline \multirow[b]{2}{*}{ \# } & \multirow{2}{*}{$\begin{array}{l}\text { Publication } \\
\text { First author Year } \\
\text { Country }\end{array}$} & \multirow{2}{*}{$\begin{array}{l}\text { Sample } \\
\text { size } \\
\mathbf{N}\end{array}$} & \multirow{2}{*}{$\begin{array}{l}\text { Survivor population } \\
\text { Cancer diagnosis } \\
\text { Age at study } \\
\text { Pulmotoxic exposure }\end{array}$} & \multicolumn{3}{|c|}{$\begin{array}{c}\text { Cut-offs } \\
\text { for abnormal indices }\end{array}$} & \multicolumn{3}{|c|}{$\begin{array}{c}\text { Prevalence } \\
\text { of abnormal indices }\end{array}$} \\
\hline & & & & FEV $_{1}$ & FVC & $\mathrm{FEV}_{1} / \mathrm{FVC}$ & FEV $_{1}$ & FVC & $\mathrm{FEV}_{1} / \mathrm{FVC}$ \\
\hline 1 & $\begin{array}{l}\text { De } \\
2014 \\
\text { USA }\end{array}$ & 80 & $\begin{array}{l}\text { Hodgkin, NHL, and GCT } \\
\text { Not stated } \\
\text { At least one pulmotoxic agent }\end{array}$ & $\begin{array}{l}<80 \% \\
\text { predicted }\end{array}$ & $\begin{array}{l}<80 \% \\
\text { predicted }\end{array}$ & $\begin{array}{l}<80 \% \\
\text { predicted }\end{array}$ & $11 \%$ & $9 \%$ & $14 \%$ \\
\hline 2 & $\begin{array}{l}\text { De } \\
2015 \\
\text { USA }\end{array}$ & 49 & $\begin{array}{l}\text { All cancer diagnoses } \\
\text { Median age } 34 \text { years } \\
\text { At least one pulmotoxic agent }\end{array}$ & $\begin{array}{l}<80 \% \\
\text { predicted }\end{array}$ & $\begin{array}{l}<80 \% \\
\text { predicted }\end{array}$ & $\begin{array}{l}<80 \% \\
\text { predicted }\end{array}$ & $29 \%$ & $24 \%$ & $14 \%$ \\
\hline 3 & $\begin{array}{l}\text { Denbo } \\
2014 \\
\text { USA }\end{array}$ & 21 & $\begin{array}{l}\text { Osteosarcoma } \\
\text { Mean age } 35 \text { years } \\
\text { At least one pulmotoxic agent }\end{array}$ & $\begin{array}{l}<80 \% \\
\text { predicted }\end{array}$ & $\begin{array}{l}<80 \% \\
\text { predicted }\end{array}$ & -- & $48 \%$ & $40 \%$ & -- \\
\hline 4 & $\begin{array}{l}\text { Green } \\
2015 \\
\text { USA, Canada, Australia }\end{array}$ & 260 & $\begin{array}{l}\text { Embryonal brain tumors } \\
\text { Not stated } \\
\text { At least one pulmotoxic exposure }\end{array}$ & $\begin{array}{l}<80 \% \\
\text { predicted }\end{array}$ & $\begin{array}{l}<80 \% \\
\text { predicted }\end{array}$ & -- & $29 \%$ & $28 \%$ & -- \\
\hline 5 & $\begin{array}{l}\text { Inaba } \\
2010 \\
\text { USA }\end{array}$ & 89 & $\begin{array}{l}\text { Leukemia with HSCT } \\
\text { Not stated } \\
\text { At least one pulmotoxic exposure }\end{array}$ & $\begin{array}{l}<80 \% \\
\text { predicted }\end{array}$ & $\begin{array}{l}<80 \% \\
\text { predicted }\end{array}$ & $\begin{array}{l}<80 \% \\
\text { predicted }\end{array}$ & $36 \%$ & $39 \%$ & $23 \%$ \\
\hline 6 & $\begin{array}{l}\text { Jenney } \\
1995 \\
\text { UK }\end{array}$ & 69 & $\begin{array}{l}\text { Leukemia } \\
\text { Median } 15 \text { years } \\
\text { With and without pulmotoxic exposure }\end{array}$ & $\begin{array}{l}<80 \% \\
\text { predicted }\end{array}$ & $\begin{array}{l}<80 \% \\
\text { predicted }\end{array}$ & -- & $23 \%$ & $20 \%$ & -- \\
\hline 7 & $\begin{array}{l}\text { Leung } \\
2007 \\
\text { USA }\end{array}$ & 155 & $\begin{array}{l}\text { Leukemia with HSCT } \\
\text { Median age } 19 \text { years } \\
\text { At least one pulmotoxic exposure }\end{array}$ & -- & -- & $\begin{array}{l}<85 \% \\
\text { predicted }\end{array}$ & -- & -- & $27 \%$ \\
\hline 8 & $\begin{array}{l}\text { Motosue } \\
2012 \\
\text { USA }\end{array}$ & 48 & $\begin{array}{l}\text { Solid tumors } \\
\text { Adolescent and adult } \\
\text { At least one pulmotoxic agent }\end{array}$ & $\begin{array}{l}<80 \% \\
\text { predicted }\end{array}$ & $\begin{array}{l}<80 \% \\
\text { predicted }\end{array}$ & $\begin{array}{l}<80 \% \\
\text { predicted }\end{array}$ & $65 \%$ & $58 \%$ & $23 \%$ \\
\hline
\end{tabular}




\begin{tabular}{|c|c|c|c|c|c|c|c|c|c|}
\hline 9 & $\begin{array}{l}\text { Mulder } \\
2011 \\
\text { The Netherlands }\end{array}$ & 193 & $\begin{array}{l}\text { All cancer diagnoses } \\
\text { Median age } 27 \text { years } \\
\text { At least one pulmotoxic exposure }\end{array}$ & $\begin{array}{l}<80 \% \\
\text { predicted }\end{array}$ & $\begin{array}{l}<75 \% \\
\text { predicted }\end{array}$ & $\begin{array}{l}<70 \% \\
\text { predicted }\end{array}$ & $21 \%$ & $18 \%$ & $3 \%$ \\
\hline 10 & $\begin{array}{l}\text { Nysom } \\
1998 \\
\text { Denmark }\end{array}$ & 41 & $\begin{array}{l}\text { Hodgkin and NHL } \\
\text { Median age } 21 \text { years } \\
\text { At least one pulmotoxic exposure }\end{array}$ & $\begin{array}{l}\text { LLN } \\
\text { z score - } \\
1.64\end{array}$ & $\begin{array}{l}\text { LLN } \\
\text { z score - } \\
1.64\end{array}$ & $\begin{array}{l}\text { LLN= } \\
\text { z score - } \\
1.64\end{array}$ & $27 \%$ & $27 \%$ & $10 \%$ \\
\hline 11 & $\begin{array}{l}\text { Nysom } \\
1998 \\
\text { Denmark }\end{array}$ & 94 & $\begin{array}{l}\text { Leukemia } \\
\text { Median age } 16 \text { years } \\
\text { No pulmotoxic exposure }\end{array}$ & $\begin{array}{l}\text { LLN } \\
\text { z score - } \\
1.64\end{array}$ & $\begin{array}{l}\text { LLN } \\
\text { z score - } \\
1.64\end{array}$ & $\begin{array}{l}\text { LLN } \\
\text { z score - } \\
1.64\end{array}$ & $8 \%$ & $15 \%$ & $1 \%$ \\
\hline 12 & $\begin{array}{l}\text { Record } \\
2012 \\
\text { USA }\end{array}$ & 143 & $\begin{array}{l}\text { All cancer diagnoses } \\
\text { Mean age } 14 \text { years } \\
\text { At least one pulmotoxic agent }\end{array}$ & $<80 \%$ & $<80 \%$ & $<80 \%$ & $26 \%$ & $25 \%$ & $5 \%$ \\
\hline 13 & $\begin{array}{l}\text { Weiner } \\
2006 \\
\text { USA }\end{array}$ & 30 & $\begin{array}{l}\text { Solid tumors } \\
\text { Median age } 12 \text { years } \\
\text { At least one pulmotoxic agent }\end{array}$ & $\begin{array}{l}\text { LLN } \\
\text { z score - } \\
2.00\end{array}$ & $\begin{array}{l}\text { LLN } \\
\text { z score - } \\
2.00\end{array}$ & -- & $50 \%$ & $53 \%$ & -- \\
\hline
\end{tabular}

Abbreviations: CCS, childhood cancer survivors; GCT, germ cell tumor; HSCT, hematopoietic stem cell transplantation; LLN, lower limit of normality; N, number; NHL, non-Hodgkin lymphoma 


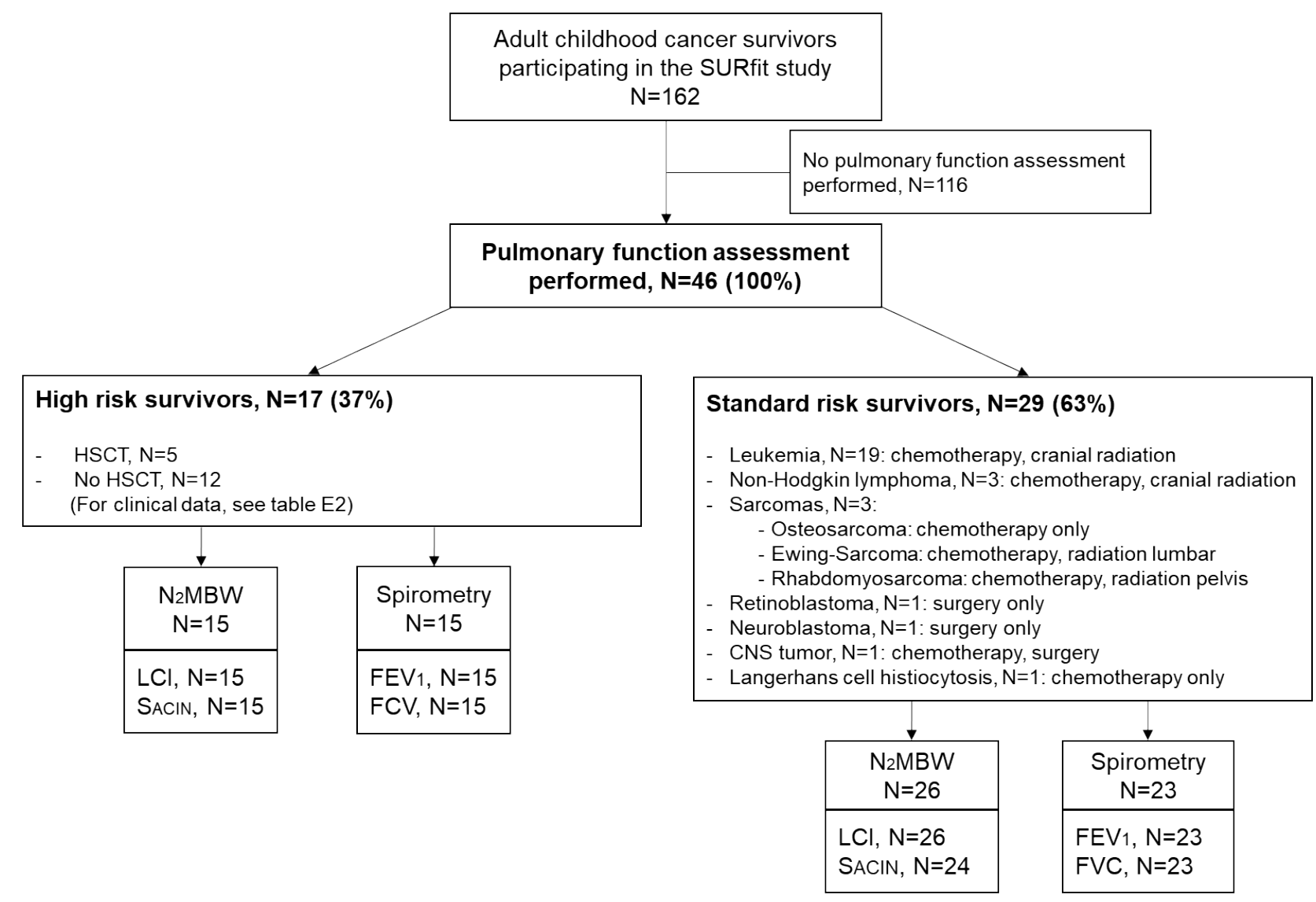

Figure E1. Population tree of study participants of the SURfit study who were recruited for a lung function assessment using $\mathrm{N}_{2} \mathrm{MBW}$ and spirometry

Abbreviations: CNS, central nervous system; LCl, lung clearance index; N, numbers; HSCT, hematopoietic stem cell transplantation; $\mathrm{N}_{2} \mathrm{MBW}$, nitrogen multiple-breath washout; $\mathrm{S}_{\mathrm{ACIN}}$, acinar ventilation inhomogeneity index 